\title{
EFEKTIVITAS LARUTAN DAUN PEPAYA (CARICA PAPAYA) TERHADAP KEMATIAN LARVA AEDES AEGYPTI
}

\author{
Gusti Syarif Hidayatullah, Isnawati, Muhammad Irfa'i \\ Poltekkes Kemenkes Banjarmasin Jurusan Kesehatan Lingkungan \\ Jl.H. Mistar Cokrokusumo No.1A Banjarbaru Kalimantan Selatan 70714 \\ E-mail: gustisyarif870@gmail.com
}

\begin{abstract}
Effectiveness Of Pepaya Leaves (Carica Papaya) On The Death Of Aedes Aegypti Larva. Aedes aegypti mosquito is a type of mosquito that can carry dengue virus which causes dengue fever (DHF). Dengue transmission can be reduced by vector control to reduce the population of Aedes aegypti mosquitoes, namely by reducing larval growth. Eradication can be done by giving environmentally friendly plant larvaside. Plants that have the potential as vegetable larvasides are papaya leaves (Carica papaya).. The type of research used is true experiments. The study design uses an e-simple design (post-test only control group design). The population and sample were 3 Aedes aegypti instar larvae obtained in the Banjarbaru region. With a total of 600 tails. With variations in concentration of $0 \%$ (control), $6 \%, 8 \%, 10 \%, 12 \%$, and $14 \%$ with 4 repetitions at each concentration. then observed the number of larvae that died for 24 hours.Based on the results of research conducted for 24 hours with papaya leaf larvasidehighest concentration $14 \%$ / $100 \mathrm{ml}$ of water can kill larvae as much as $96 \%$ with an average death of 24 animals. With statistical testsAnova Ona Way is $p=0,000<a(0.05)$ it can show that there is a difference between several concentrations of the death of Aedes aegypti larvae.Thus, it can be concluded that papaya leaf solution with the highest concentration of $14 \%$ in $100 \mathrm{ml}$ of water is effective in killing instar 3 Aedes aegypti larvae.
\end{abstract}

Keywords: Level of Dust; Rubber Plant Barrier

\begin{abstract}
Abstrak: Efektivitas Larutan Daun Pepaya ( Carica Papaya) Terhadap Kematian Larva Aedes Aegypti. Nyamuk Aedes aegypti merupakan jenis nyamuk yang dapat membawa virus dengue penyebab penyakit demam berdarah (DBD). Penularan DBD dapat dikurangi dengan pengendalian vektor untuk menurunkan populasi nyamuk aedes aegypti yaitu dengan menurunkan pertumbuhan larva. Pemberantasan dapat dilakukan dengan cara memberi larvasida nabati yang ramah lingkungan. Penelitian ini bertujuan mengetahui efektivitas larvasida larutan daun pepaya (Carica papaya) terhadap kematian larva Aedes aegypti. Jenis penelitian yang digunakan adalah true eksperimen. Desain penelitian menggunakan rancangan e-sederhana (post-test only control group design). Populasi dan sampel adalah larva instar 3 Aedes aegypti yang diperoleh di wilayah Banjarbaru. Dengan total sebanyak 600 ekor. Dengan variasi konsentrasi yaitu 0\% (kontrol), 6\%, 8\%, 10\%, 12\%, dan 14\% dengan 4 kali pengulangan pada setiap konsentrasi. kemudian diamati jumlah larva yang mati selama 24 jam. Berdasarkan hasil penelitian yang dilakukan selama 24 jam larvasida daun papaya dengan konsentrasi tertinggi 14\%/100 ml air mampu membunuh larva sebanyak 96\% dengan rata-rata kematian sebanyak 24 ekor. Dengan uji statistik Anova Ona Way adalah $p=0,000<a(0,05)$ hal itu dapat menunjukkan bahwa ada perbedaan antara beberapa konsentrasi terhadap kematian larva Aedes aegypti. Dengan demikian, dapat disimpulkan bahwa larutan daun papaya dengan konsentrasi tertinggi 14\% dalam $100 \mathrm{ml}$ air efektif dalam membunuh larva Aedes aegypti instar 3.
\end{abstract}

Kata Kunci: Larva Aedes aegypti, Daun Pepaya (Carica papaya).

\section{PENDAHULUAN}

Penyakit Demam Berdarah Dengue (DBD) ditularkan melalui gigitan dari nyamuk Aedes. Penyakit ini berkaitan dengan kondisi lingkungan, iklim, mobilisasi yang tinggi, kepadatan penduduk, perluasan perumahan dan perilaku masyarakat ${ }^{[1]}$. Nyamuk Aedes 
aegypti merupakan jenis nyamuk yang dapat membawa virus dengue penyebab penyakit demam berdarah. Penyebaran jenis ini sangat luas, meliputi hampir semua daerah tropis di seluruh dunia. Aedes aegypti merupakan pembawa utama (Primary vector) [2].

Data dunia menunjukan Asia menempati urutan pertama dalam jumlah penderita DBD setiap tahunnya ${ }^{[3]}$. Berdasarkan kasus DBD di wilayah Kota Banjarbaru, kasus DBD selama tahun 2017 terjadi yaitu 56 kasus dan tahun 2018 terjadi peningkatan yaitu terdapat 269 kasus, dan ditahun 2019 dari bulan januari sampai september kasus DBD mengalami kenaikan menjadi 342 kasus.

Menurut data dari Dinas Kesehatan Kota Banjarbaru, ABJ (Angka Bebas Jentik) yang ada di wilayah kota Banjarbaru sudah bagus yaitu 87,33\%, namun program dinyatakan belum tuntas apabila ABJ belum mencapai 95\%.

Pengetahuan dan perilaku hidup seseorang yang tidak sehat dapat mengakibatkan berkembang biaknya jentik nyamuk terutama ditempat-tempat yang menjadi genangan air dan lembab. Telur nyamuk ${ }^{[4]}$.

Daun pepaya memiliki banyak kandungan zat, dimana kandungan zat tersebut beberapa diantaranya dapat membunuh larva nyamuk[5]. Berdasarkan uji pendahuluan yang dilakukan tanaman yang berpotensi sebagai larvasida nabati adalah daun pepaya (Carica papaya). Oleh karena itu peneliti ingin melakukan penelitian dengan judul efektivitas larutan daun papaya (Carica papaya) terhadap kematian larva Aedes aegypti dengan berbagai konsentrasi percobaan.

\section{BAHAN DAN CARA PENELITIAN}

Jenis penelitian yang digunakan adalah true eksperimen (eksperimen murni), yaitu mengetahui variasi konsentrasi terhadap kematian larva Aedes aegypti.

Desain penelitian ini menggunakan rancangan post-test only control group design rancangan penelitian yang terdiri dari kelompok kontrol dan kelompok eksperimen. ${ }^{5]}$.

Teknik sampling digunakan pada penelitian tersebut adalah Simple Random Sampling. Metode ini dilakukan karena pengambilan sampel populasi dilakukan secara acak[7]. Jumlah sampel sebanyak 600 ekor larva dengan masing-masing konsentrasi yang dilakukan yaitu $0 \%$ (kontrol), 6\%, 8\%, 10\%, 12\%, dan 14\% untuk setiap $100 \mathrm{ml}$ air. Dan kontak waktu yang digunakan yaitu selama 24 jam. [7]

Metode pengumpulan data dengan cara Observasi. Yaitu proses pengamatan dan pendokumentasian hal-hal yang terjadi selama tindakan berlangsung. Data yang diperoleh dimasukkan pada tabel distribusi frekuensi untuk mengetahui konsentrasi efektif larutan daun papaya terhadap kematian larva aedes aegypti, Kemudian data diolah dengan menggunakan metode One Way Anova. Penelitian ini dilakukan pada bulan oktober 2019 sampai dengan bulan mei 2020 di rumah peneliti.

\section{HASIL PENELITIAN DAN PEMBAHASAN}

Dari table hasil pengamatan terhadap banyaknya larva yang mati dilihat pada table di bawah.

Tabel 1. Hasil Pengamatan Kematian Larva

\begin{tabular}{|c|c|c|c|c|c|c|c|}
\hline \multicolumn{2}{|c|}{ Jenis Larva } & & & & \multirow{3}{*}{ Jumlah } & \multirow{3}{*}{$\begin{array}{l}\mathrm{pH} \\
\text { Air }\end{array}$} & \multirow{3}{*}{$\begin{array}{l}\text { Suhu } \\
\text { Air }\end{array}$} \\
\hline \multirow{2}{*}{ Konsentrasi } & & & & & & & \\
\hline & R1 & $\mathrm{R} 2$ & R3 & R4 & & & \\
\hline $0 \%$ & 0 & 0 & 0 & 0 & 0 & 7.3 & $30,6^{\circ} \mathrm{C}$ \\
\hline $6 \%$ & 5 & 4 & 5 & 6 & 20 & 7.3 & $30,6^{\circ} \mathrm{C}$ \\
\hline $8 \%$ & 7 & 7 & 9 & 8 & 31 & 7.3 & $30,6^{\circ} \mathrm{C}$ \\
\hline $10 \%$ & 10 & 11 & 12 & 11 & 44 & 7.3 & $30,6^{\circ} \mathrm{C}$ \\
\hline $12 \%$ & 18 & 19 & 19 & 20 & 76 & 7.3 & $30,6^{\circ} \mathrm{C}$ \\
\hline $14 \%$ & 24 & 25 & 23 & 24 & 96 & 7.3 & $30,6^{\circ} \mathrm{C}$ \\
\hline
\end{tabular}


Pada tabel 1 menunjukkan bahwa kemampuan larutan daun papaya dalam mematikan larva nyamuk tersebut dengan 4 kali pengulangan didapatkan angka kematian larva terendah pada konsentrasi $6 \% / 100 \mathrm{ml}$ air sebanyak 20 ekor (20\%) larva instar 3 dengan waktu kontak selama 24 jam. Dan angka kematian tertinggin pada konsentrasi $14 \% / 100 \mathrm{ml}$ air dengan 4 kali pengulangan sebanyak 96 ekor (96\%) larva instar 3 dengan waktu kontak selama 24 jam.

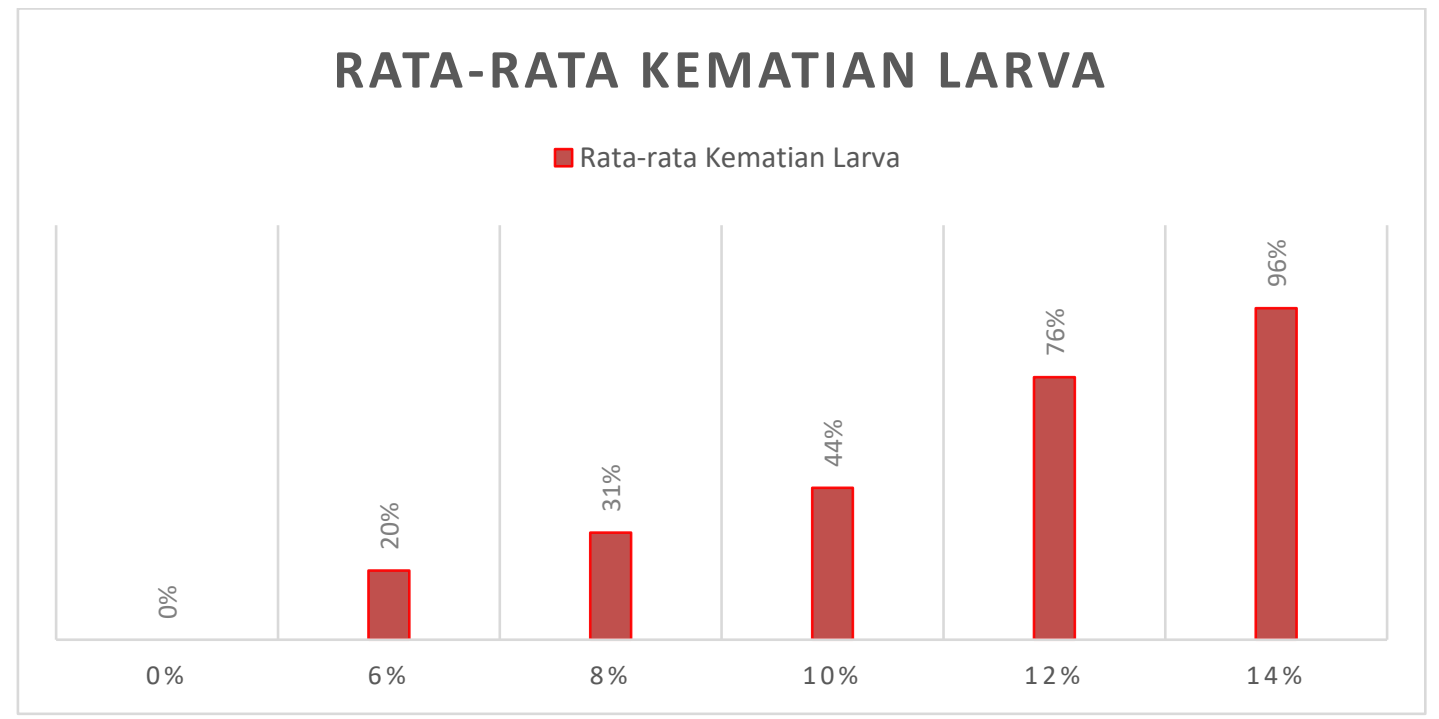

Gambar 1 Grafik Rata-Rata Kematian Larva Nyamuk Aedes aegypti

Pada gambar grafik diatas dilihat bahwa semakin tinggi konsentrasi dan semakin lama waktu kontak yang diberikan maka akan semakin tinggi pula tingkat kematian larva nyamuk yang dihasilkan

Variasi Konsentrasi Larutan Daun Pepaya (Carica papaya L.) terhadap kematian larva Aedes aegypti.

Pada uji pendahuluan yang dilakukan untuk mendapatkan LC 50 perndahuluan. Konsentrasi yang digunakan pada percobaan yaitu $0 \%$ (kontrol), 6\%, 8\%, $10 \%$, $12 \%$, dan $14 \%$, dengan masingmasing kontainer berisikan 10 ekor larva
Aedes aegypti. Kemudian untuk menentukan LC 50 menggunakan aplikasi miniTab didapatkan hasil lower 7,64668\% dan Upper 9,65796\% dalam 100ml air. Dari hasil tersebut dapat diketahui konsentrasi larutan yang dapat membunuh 50\% larva pada konsentrasi Estimate 8,72255\%. Yang artinya konsentrasi tersebut dapat digunakan untuk uji toksisitas lanjutan.

Lethal Consentration $50 \%$ (LC 50) Larutan Daun Pepaya (Carica papaya L.) Terhadap Kematian Larva Aedes aegypti. 
Tabel 2. Hasil Uji Probit

\begin{tabular}{cccc} 
Nilai LC & Estimate & Lower & Upper \\
\hline LC 50 & 9.57286 & 9.15651 & 9.98546 \\
LC 90 & 13.8028 & 13.1279 & 14.6803
\end{tabular}

Pada tabel 2 dari hasil tersebut dapat diketahui konsentrasi yang dapat membunuh $50 \%$ pada konsentrasi 9.57286\%. Berdasarkan hasil penelitian yang dilakukan dan diuji dengan uji normalitas kemudian dilanjutkan dengan uji One Way Anova dan Post hoc.

\section{Analisis Perbedaan Efektivitas Variasi Konsentrasi Pada Setiap Perlakuan .}

Larvasida daun papaya pada konsentrasi 14\%/100 ml air sudah dapat membunuh larva dengan rata-rata 96\% kematian dengan cara dihaluskan menggunakan juicer, lalu langsung dijadikan larvasida. Hal ini menyimpulkan konsentrasi 14\% /100 ml air daya bunuh tinggi dibandingkan dengan konsentrasi yang lain. Tingginya tingkat kematian larva pada konsentrasi 14\% dikarenakan beberapa kandungan senyawa aktif yang ada pada daun papaya kontak langsung dengan larva uji selama penelitian.

Dalam hal tersebut banyak kandungan zat aktif yang ada didalam larutan daun papaya yang menyebabkan larva mati. Salah satu kandungan dari daun papaya yang dapat membunuh larva nyamuk Aedes aegypti adalah Tanin.
Menurut penelitian yang dilakukan oleh (Setyaningsih 2016). Menyimpulkan bahwa tanin dapat menghalangi dalam mencerna makanan dan juga menyebabkan gangguan penyerapan air pada organisme sehingga dapat mematikan organisme [8]

Sejalan dengan penelitian Hayatie Lisda, dkk (2015). Dari penelitian ini menyimpulkan bahwa keberadaan konstituen phytochemical suc ah flavonoid, alkaloid dan tannin dalam biji dan kulit pepaya mungkin menjadi alasan untuk aktivitas larvasidanya terhadap Aedes aegypti. Hasil percobaan ini menunjukkan bahwa dapat dipelajari lebih lanjut secara rinci dan efektivitasnya bermanfaat untuk pengendalian penyakit yang ditularkan melalui vektor dapat dimanfaatkan untuk lingkungan yang sehat. [9]

Sependapat dengan penelitian Fatnassi Bassem, et al 2014. mengatakan bahwa ekstrak air dan ekstrak daun memiliki kandungan salah satunya Tanin yang digunakan sebagai senyawa ramah lingkungan terhadap kematian larva nyamuk.[10]

Tabel 3. Hasil Uji Normalitas Data

\begin{tabular}{ccc}
\hline Konsentrasi & Nilai Sig. & Keterangan \\
\hline $0 \% / 100 \mathrm{ml}$ air & - & Kontrol \\
$6 \% / 100 \mathrm{ml}$ air & 0,683 & Berdistribusi Normal \\
$8 \% / 100 \mathrm{ml}$ air & 0,272 & Berdistribusi Normal \\
$10 \% / 100 \mathrm{ml}$ air & 0,683 & Berdistribusi Normal \\
$12 \% / 100 \mathrm{ml}$ air & 0,683 & Berdistribusi Normal \\
$14 \% / 100 \mathrm{ml}$ air & 0,683 & Berdistribusi Normal \\
\hline
\end{tabular}

Berdasarkan tabel 3 diatas hasil uji normalitas data nilai yang signifikan semua data berdistribusi normal maka dilanjutkan dengan uji One Way Anova. Hasilnya $\mathrm{p}=0,000<0,05$ (a) yang artinya ada beda antara beberapa konsentrasi 
terhadap kematian larva Aedes aegypti instar 3, dan dilanjutkan dengan hasil uji

\section{KESIMPULAN DAN SARAN}

Pada pengujian larvasida menggunakan larutan daun papaya kematian terkecil pada konsentrasi $6 \% / 100 \mathrm{ml}$ air adalah sebanyak 20 ekor (20\%) larva instar 3, dengan rata-rata kematian larva 5 ekor. dan konsentrasi tertinggi $14 \% / 100 \mathrm{ml}$ air sebanyak 96 ekor (96\%) larva instar 3. dengan ratarata kematian larva 24 ekor.

Daun papaya efektif dalam membunuh larva Aedes aegypti, dengan hasil LC50 daun papaya yaitu 9,5\%/100ml air atau 9,5 ml/100 ml air dan LC90 sebesar 13,8\%/100ml air atau $13,8 \mathrm{ml} / 100 \mathrm{ml}$ air.

Hasil $\mathrm{p}=0,000<\mathrm{a}(0,05)$ yang artinya ada beda antara beberapa konsentrasi terhadap kematian larva Aedes aegypti instar 3.

Namun dalam penggunaanya daun papaya memiliki bau yang sangat menyengat dan dapat mempengaruhi warna air pada air tersebut. Dan cara yang digunakan untuk mengatasi warna pada air tersebut dengan cara dilakukannya penyaringan menggunakan kertas saring lebih dari satu kali untuk menurunkan warna agar tidak terlalu pekat dan kandungan di dalam air tetap sama.

\section{KEPUSTAKAAN}

1. Kemenkes. (2018). Profil Kesehatan Indonesia 2018 [Indonesia Health Profile 2018].

2. Anggraeni, Dini Siti. (2010). Stop Demam Berdarah Dengue, Bogor.

3. WHO/SEARO. 1998. Comprehensive lanjutan LSD/ Analisis PostHoc

Guidelines for Prevention and Control of Dengue and Dengue Haemorrhagic Fever. WHO Regional Publication SEARO No.29.

4. Borror, T. dan N.F. Johnson. 1989. Pengenalan Pelajaran Serangga. Edisi Keenam. Yogyakarta : Universitas Gajah Mada Press.

5. Kondo, M., K. Kita And H. Yokota. (2004). Feeding value to goats of whole-crop oat ensiled with green tea waste. Anim. Feed Sci. Technol. 113: 71-81.

6. Notoatmodjo,S.(2010). Metodologi Penelitian Kesehatan. Jakarta: PT. Rineka Cipta.

7. Notoatmodjo, S. 2012. Metedologi Penelitian Kesehatan. Edisi Revisi Cetakan Kedua, Jakarta: Rineka Cipta.

8. Setyaningsih. (2016). Efektivitas Ekstrak Ethanol Daun Salam Sebagai Larvasida Terhadap Larva Nyamuk Aedes aegypti. Skripsi. Denpasar: Universitas Udayana.

9. Hayatie, Lisda, dkk (2015). Aqueous Extracts of Seed and Peel of Carica Papaya Against Aedes Aegypti. Department of Medical Pharmacology Faculty of Medicine Lambung Mangkurat University, Banjarmasin, Indonesia.

10. Bassem, F, et al. (2014). Larvicidal efficacy of Jatropha curcas $L$. (Euphorbiaceae) leaf and seed aqueous extracts against Culex pipiens $L$. Department of Biology, faculty of sciences of Bizerte, University of Carthage, Tunisia. 
